\title{
PENGACUAN DEIKSIS PERSONA DALAM CERPEN PADA KORAN SUARA MERDEKAONLINE EDISI NOVEMBER 2018
}

\author{
Reza Ayu Maharani \\ Pujiati Suyata \\ Program Pendidikan Bahasa dan Sastra Indonesia \\ Fakultas Keguruan dan Ilmu Pendidikan \\ Universitas Ahmad Dahlan \\ rezaayumaharani@gmail.com
}

\begin{abstract}
ABSTRAK
Deiksis persona adalah pronomina yang dipakai untuk mengacu pada diri sendiri, mengacu pada orang yang diajak bicara, atau mengacu pada orang yang dibicarakan. Adapun permasalahan yang ditemukan dalam penelitian ini adalah belum diketahui adanya pengacuan deiksis persona dalam kumpulan cerpen pada koran Suara Merdeka Online Edisi November 2018. Jenis penelitian ini adalah deskriptif kualitatif. Metode pengumpulan data yang digunakan dalam penelitian ini adalah simak dan catat. Instrumen dalam penelitian ini adalah teori deiksis persona. Metode analisis data yang digunakan adalah metode padan dengan menggunakan teknik dasar PUP (Pilah Unsur Penentu). Hasil penelitian menunjukan bahwa pengacuan deiksis persona dalam kumpulan cerpen pada koran Suara Merdeka Online Edisi November 2018 meliputi pengacuan eksofora dan endofora. Deiksis eksofora terdapat pada deiksis persona pertama, yaitu sebanyak 36 data. Deiksis endofora pengacuan anafora yang ditemukan sebanyak 31 data, sedangkan pada pengacuan katafora yang ditemukan sebanyak 1 data.
\end{abstract}

Kata kunci: deiksis persona, deksis endofora, deiksis katafora

\section{A. PENDAHULUAN}

Manusia dan bahasa merupakan dua komponen yang tidak bisa saling dipisahkan. Bahasa sebagai sarana komunikasi yang dapat menghubungkan interaksi antara manusia satu dengan manusia lain di dalam suatu masyarakat. Bahasa dapat digunakan sebagai sarana komunikasi langsung atau lisan dan sarana komunikasi tidak langsung atau tertulis. Sebagai sarana komunikasi tidak langsung atau tertulis bahasa dapat diwujudkan pada karya sastra prosa, seperti cerpen, novel, dongeng, ataupun cerita rakyat. Cerpen atau cerita pendek sebagai sebuah karangan atau wacana yang dapat mentransfer pesan-pesan, pelukisan tokoh, alur, latar, serta unsur-unsur intrinsik lainnya kepada pembaca dalam bentuk tertulis atau melalui media bahasa tidak langsung. 
Selain semantik dan semiotik dalam bahasa yang mengkaji makna adapula pragmatik. Menurut Verhaar $(2012,14)$, "Menyatakan bahwa pragmatik merupakan cabang ilmu linguistik yang membahas tentang apa yang termasuk struktur bahasa sebagai alat komunikasi antara penutur dan pendengar, dan sebagai pengacuan tanda-tanda bahasa pada hal-hal ekstralingual yang dibicarakan.” Objek kajian pragmatik yang berupa bahasa di dalam masyarakat berupa karya sastra, karya tulis, tuturan, dan lainnya. Penelitian ini menggunakan objek kajian pragmatik berupa karya sastra. Kajian-kajian yang terkandung dalam suata karya sastra pada pragmatik, antara lain implikatur, deiksis, tindak tutur, prinsip kerja sama, dan lain sebagainya.

Salah satu topik dalam pembahasan pragmatik adalah deiksis. Menurut Yule (2014: 13) istilah deiksis berasal dari bahasa Yunani, yaitu salah satu hal mendasar yang kita lakukan dengan tuturan. Deiksis adalah hubungan antara bahasa dengan konteks yang menunjuk sesuatu di luar bahasa. Jenis deiksis sendiri di kelompokan menjadi empat macam. Namun, dalam penelitian ini hanya akan dibahas satu deiksis, yaitu deiksis persona. Menurut Alwi, dkk. (2010: 256) deiksis persona adalah kata ganti yang menunjuk pada diri atau orang. Kata ganti yang merujuk pada dirinya sendiri ( kata ganti orang pertama), orang yang sedang berbicara (kata ganti orang kedua), orang yang sedang dibicarakan (kata ganti orang ketiga).

Pengacuan deiskis persona ada dua, yaitu deiksis persona eksofora dan deiksis persona endofora. Eksofora terbagi menjadi dua, yaitu eksofora persona pertama dan eksofora persona kedua, sedangkan endofora terbagi menjadi pengacuan anafora dan pengacuan katafora (Putrayasa, 2014: 58).

Seiring perkembangan zaman penggunaan deiksis persona dapat ditemukan dimedia internet, misalnya Kompas, Suara Merdeka,Okezon, Babe, Liputan 6,Detikcom, dan lain sebagainya. Pada penelitian ini menemukan penggunaan deiksis persona pada kumpulan cerpen yang terdapat dalam media internet, yaitu Suara Merdeka.Suara Merdeka merupakan surat kabar yang terbit di kota Semarang, Jawa Tengah, Indonesia.

Salah satu karya sastra yang bisa di kaji menggunakan deiksis persona adalah cerpen. Cerpen adalah cerita pendek yang bersifat fiksi mengenai kehidupan tokoh yang penuh pertikaian, baik menyedihkan atau menyenangkan, dan mengandung pesan yang sulit dilupakan.

Alasan penelitian ini tertarik memilih cerpen karena cerpen yang terdapat dalam kumpulan cerpen pada koran Suara Merdeka Online lebih variatif berisi cerpen yang beragam, dengan banyaknya cerpen maka semakin banyak pula dijumpai deiksis. Di samping itu, sudut pandang 
penokohan yang beranekaragam dan macam-macam tokoh yang berperan juga berpengaruh pada penggunaan deiksis persona yang terdapat dalam kumpulan cerpen pada koran Suara Merdeka Online Edisi November 2018. Hal tersebut menyebabkan penggunaan deiksis persona yang digunakan dapat beraneka ragam. Selain ketertarikan memilih cerpen, adapun alasan penelitian ini memilih kumpulan cerpen online karena cerpen online edisi cerpennya terbaru dengan terbit satu minggu sekali. Selain itu, pengarang cerpen tersebut berbeda-beda dari berbagai macam pengarang.

Terdapat perbedaan kajian ini dengan kajian Taufik dengan judul "Deiksis Persona Bahasa Indonesia Dialek Ambon” yang dimuat di Totobuang Vol 5, No 2 (2017). Pada kajian tersebut membahas tentang bentuk-bentuk deiksis persona, sedangkan pada kajian ini membahas tentang pengacuan deiksis persona.

Perbedaan kedua, kajian yang dilakukan oleh Mery Ansiska dengan judul "Penggunaan Deiksis Persona dan Tempat dalam Novel Supernova 1 Karya Dee" yang dimuat di Jurnal Pendidikan dan Pembelajaran Khatulistiwa Vol 3, No 3 (2014). Pada kajian ini membahas tentang penggunaan deiksis persona dan tempat serta fungsi dan makna deiksis yang terkandung dalam novel Supernova 1: Kesatria, Putri, dan Binatang Jatuh karya Dee, sedangkan pada kajian ini membahas tentang pengacuan deiksis persona.

Perbedaan ketiga, kajian yang dilakukan oleh Syaiful Abid dengan judul "Deiksis Persona Bahasa Musi Desa Pulau Panggung Kecamatan Muara Kelingi Kabupaten Musi Rawas” yang dimuat di Jurnal Perspektif Pendidikan Vol 8, No 2 (2014). Pada kajian ini membahas tentang bentuk dan pemakaian deiksis persona bahasa Musi Desa Pulau Panggung, sedangkan pada kajian ini membahas tentang pengacuan deiksis persona.

\section{B. KAJIAN TEORI}

Deiksis persona terdiri dari tiga bentuk, yaitu deiksis persona pertama, deiksis persona kedua, deiksis persona ketiga (Alwi, dkk., 2010: 256).

\section{1) Deiksis Persona Pertama}

Menurut Alwi, dkk. (2010: 258), "Menyatakan deiksis persona pertama merupakan kata ganti yang menggantikan diri orang penutur atau yang berbicara. Bentuk deiksis persona pertama, yaitu pronomina aku, saya, kita, dan kami.'Deiksis persona pertama terdiri dari deiksis persona pertama tunggal dan jamak. 


\section{a) Deiksis Persona Pertama Tunggal}

Menurut Alwi, dkk. (2010: 258) deiksis persona pertama tunggal adalah kata yang menggantikan diri orang penutur atau yang berbicara dan memiliki acuan satu orang. Pronomina persona pertama tunggal dalam bahasa Indonesia terdiri dari saya, aku, dan daku.

\section{b) Deiksis Persona Pertama Jamak}

Menurut Alwi, dkk. (2010: 259) deiksis persona pertama jamak ada dua, yaitu kami dan kita. Kami bersifat eksklusif, artinya kata ganti itu meliputi pembicara/penulis dan orang lain dipihaknya, tetapi tidak menyertakan orang lain dipihak pendengar/pembaca. Sebaliknya, kita bersifat inklusif, artinya kata ganti itu tidak hanya meliputi pembicara/penulis, tetapi juga pendengar/pembaca, dan mungkin pula pihak lain.

\section{2) Deiksis Persona Kedua}

Menurut Alwi, dkk. (2010: 260) deiksis persona kedua merupakan kata ganti yang menggantikan diri orang yang diajak bicara. Bentuk deiksis persona kedua jamak, yaitu pronomina kamu, engaku, Anda dan kalian. Pronomina persona kamu dan engkau mempunyai bentuk singkat, yaitu mu dan kau. Deiksis persona kedua terdiri dari pronomina persona kedua tunggal dan jamak.

\section{a) Deiksis Persona Kedua Tunggal}

Menurut Alwi, dkk. (2010: 260)deiksis persona kedua tunggal mempunyai beberapa wujud, yakni kamu, -mu, engkau, dikau, kau-, dan Anda. Bentuk deiksis

persona kedua tunggal digunakan oleh orang tua terhadap orang muda yang sudah dikenal, orang-orang dari status sosial tinggi dan orang-orang yang memiliki hubungan dekat tanpa memandang status sosial atau usia.

\section{b) Deiksis Persona Kedua Jamak}

Menurut Alwi, dkk. (2010: 261) deiksis persona kedua jamak terdiri dari dua macam, antara lain kalian, dan persona kedua ditambah dengan kata sekalian. Meskipun kalian tidak terikat dengan etika sosial, tidak boleh dipakai oleh kaum muda atau orang-orang dengan status sosial yang lebih rendah terhadap orang tua atau atasannya. Pada pemakaian kamu sekalian atau andasekalian sama dengan penggunaan 
untuk pronomina dasarnya, kamu dan Anda, kecuali dengan tambahan pengertian kejamakan.

\section{3) Deiksis Persona Ketiga}

Menurut Alwi, dkk. ( 2010: 260) deiksis persona ketiga merupakan kata ganti yang menggantikan orang yang dibicarakan. Bentuk deiksis persona ketiga, yaitu pronomina $i a$, dia, -nya, beliau, dan mereka. Deiksis persona ketiga terdiri dari pronomina persona kedua tunggal dan jamak.

\section{a) Deiksis Persona Ketiga Tunggal}

Menurut Alwi, dkk. (2010: 261) deiksis persona ketiga tunggal terdiri dari beberapa bentuk, yaitu ia, dia, -nya, dan beliau. Pronomina persona ia dan dia memiliki fungsi yang sama dalam banyak hal dan ada beberapa perbedaan tertentu dari masing-masing pronomina tersebut. Posisi sebagai subjek, atau sebelum kata kerja ia dan dia dapat digunakan. Akan tetapi, jika berfungsi sebagai objek, atau terletak di sebalah kanan dari yang dijelaskan, hanya bentuk dia dan nya yang dapat muncul. Demikian pula dalam hal preposisi, dia dan -nya dapat digunakan, tetapi ia tidak.

\section{b) Deiksis Persona Ketiga Jamak}

Deiksis persona ketiga jamak adalah mereka. Pada umumnya mereka hanya dipakai untuk insan. Pada cerita fiksi, kata mereka kadang-kadang juga dipakai untuk mengacu pada benda yang dianggap bernyawa atau binatang (Alwi, dkk., 2010: 265).

\section{Pengacuan Deiksis Persona}

Alwi, dkk. (2010: 44) menyatakan "Pengacuan atau referensi adalah hubungan antara bahasa atau wujud yang meliputi benda atau hal yang diacu oleh satuan bahasa itu."

Menurut Putrayasa (2014: 58) arah acuan deiksis persona berdasarkan letak acuannya, dibagai menjadi dua, yaitu deiksis eksofora dan endofora. Deiksis luar tuturan atau luar ujaran disebut dengan eksofora, sedangkan deiksis dalam tuturan atau dalam ujaran disebut endofora.

\section{1) Deiksis Eksofora}

Deiksis eksofora atau deiksis luar tutuan adalah deiksis yang acuannya di luar teks verbal, di luar apa yang apa yang diujarkan atau dituturkan, berada pada konteks situasi (Putrayasa, 2014: 58).

Deiksis eksofora terjadi pada pronomina persona pertama dan pronomina persona kedua. Deiksis persona pertama terdiri dari pronomina persona aku, saya, kita, dan kami. 


\section{(a) Deiksis Persona Pertama}

Deiksis persona pertama yang termasuk deiksis eksofora terdiri dari aku, saya, kita, dan kami.

\section{(b) Deiksis Persona Kedua}

Deiksis persona kedua yang termasuk deiksis eksofora terdiri dari pronomina persona kamu, -mu, Anda, dan kalian.

\section{2) Deiksis Endofora}

Putrayasa (2014: 59) deiksis persona ketiga dengan pengacuan endofora terdiri dari dua jenis, yaitu anafora, dan katafora. Di dalam sebuah tuturan deiksis persona yang mengacu antaseden di dalamnya atau endofora dapat berposisi di depan atau di belakangnya. Acuan yang berada sebelumnya disebut anafora dan sebaliknya bila acuan berada sesudahnya disebut katafora.

Menurut Alwi, dkk., (2010: 43) anafora adalah rujuk silang dengan hal atau kata yang telah dinyatakan sebelumnya, sedangkan katafora adalah rujuk silang terhadap antesedan yang ada di belakangnya.

\section{(a) Deiksis Persona Ketiga Pengacuan Anafora}

Deiksis persona ketiga untuk jenis anafora terdiri dari pronomina persona $-n y a$, dia, dan mereka.

\section{(b) Deiksis Persona Ketiga Pengacuan Katafora}

Deiksis persona ketiga yang bersifat katafora hanya ditemukan pada pronomina persona -nya dan dia. pronomina persona -nya sendiri hanya mengacu persona ketiga tunggal.

\section{METODE PENELITIAN}

Jenis penelitian ini adalah deskriptif kualitatif. Metode pengumpulan data yang digunakan dalam penelitian ini adalah simak dan catat. Instrumen dalam penelitian ini adalah teori deiksis persona. Metode analisis data yang digunakan adalah metode padan dengan menggunakan teknik dasar PUP (Pilah Unsur Penentu). 


\section{HASIL DAN PEMBAHASAN}

\section{Hasil Penelitian}

Pada kumpulan cerpen pada koran Suara Merdeka Online Edisi November 2018 ditemukan mengenai arah acuan deiksis persona, antara lain deiksis persona eksofora dan deiksis endofora. Eksofora terbagi menjadi dua, yaitu eksofora persona pertama dan eksofora persona kedua, sedangkan endofora terbagi menjadi dua juga, yaitu pengacuan anafora dan katafora.

\section{Pembahasan}

\section{Deiksis Eksofora}

Deiksis eksofora atau deiksis luar tutuan adalah deiksis yang acuannya di luar teks verbal, di luar apa yang apa yang diujarkan atau dituturka, berada pada konteks situasi. Deiksis eksofora terjadi pada pronomina persona pertama dan pronomina persona kedua. Deiksis persona pertama terdiri dari pronomina persona aku, saya, kita, dan kami.

\section{a. Deiksis Persona Pertama}

Deiksis persona pertama yang termasuk deiksis eksofora pada kumpulan cerpen pada koran Suara Merdeka Online edisi November 2018, yaitu pronomina persona aku dan kami. Penggunaan tersebut, dapat dilihat dalam data berikut.

1) Sejak kecil akutidak pernah jauh dari asap. (01/01-NA)

2) "Bu Asih, inilah pendidikan kita saat ini. Jika ingin selamat tak usah terlalu idealis. Nanti malah celaka." (MG)

Pada data (1) dan (2) di atas termasuk dalam deiksis eksofora persona pertama karena acuannya berada di luar tuturan. Data (1) terdapat pronomina persona $a k u$. Pronomina persona $a k u$ tidak dapat diketahui mengacu siapa jika tidak mengetahui alur ceritanya. Berdasarkan alur ceritanya $a k u$ mengacu kepada tokoh yang menuliskan cerpen itu sendiri, yaitu Angga T Sanjaya, sedangkan data (2) terdapat pronomina persona kita. Pronomina persona kita tidak dapat diketahui mengacu siapa jika tidak mengetahui alur ceritanya. Berdasarkan alur ceritanya kita mengacu kepada Bu Asih dan Bu Sulasih.

\section{b. Deiksis Persona Kedua}

Pada kumpulan cerpen yang terdapat dalam koran Suara Merdeka Online Edisi November 2018, tidak ditemukan data yang termasuk dalam deiksis eksofora persona kedua.

\section{Deiksis Endofora}

Deiksis endofora adalah deiksis persona yang letak acuan berada di dalam tuturan. Deiksis persona ketiga dengan pengacuan endofora terdiri dari dua jenis, yaitu anafora, dan 
katafora. Di dalam sebuah tuturan deiksis persona yang mengacu antaseden di dalamnya atau endofora dapat berposisi di depan atau di belakangnya. Jika acuannya berada sebelumnya maka disebut anafora dan sebaliknya bila berada sesudahnya disebut katafora.

\section{a. Deiksis Persona Ketiga Pengacuan Anafora}

Pada deiksis persona ketiga untuk jenis anafora yang ditemukan dalam kumpulan cerpen pada koran Suara Merdeka Online Edisi November 2018, yaitu dia dan mereka. Penggunaan tersebut, dapat dilihat dalam data berikut.

3) Tak ada yang menarik, sehingga Ana tak beranjak. Dia tetap menekuri buku Pinokio. (02/02-GITSHM)

4) Dulu aku pacar Vita, Anak Ibu. Kemana dia sekarang? "tanya lelaki itu sembari meneteskan air mata.” (03/21-SKDL)

Pada data (3) di atas terdapat pronomina persona dia mengacu orang yang sedang dibicarakan dan termasuk deiksis endofora yang bersifat anafora karena mengacu tokoh dalam tuturan dan berada sebelumnya. Berdasarkan data di atas pronomina persona dia mengacu Ana. Hal itu terlihat jelas pada tuturan di atas. Acuan yang ada di dalam tuturan tersebut menyebabkan dia bersifat endofora, sedangkan pada data (4) dia mengacu orang yang sedang dibicarakan dan termasuk deiksis endofora yang bersifat anafora karena mengacu tokoh dalam tuturan dan berada sebelumnya. Berdasarkan data di atas pronomina persona dia mengacu Vita. Hal itu terlihat jelas pada tuturan di atas. Acuan yang ada di dalam tuturan tersebut menyebabkan dia bersifat endofora.

\section{b. Deiksis Persona Ketiga Pengacuan Katafora}

Deiksis persona ketiga yang terdapat dalam kumpulan cerpen pada koran Suara Merdeka Online Edisi November 2018 yang bersifat katafora hanya ditemukan pada pronomina persona dia. Penggunaan tersebut, dapat dilihat dalam data berikut.

5) Dia melihat beberapa kawan masih bermain di tanah lapang depan rumah. Bola mata bening Ana menatap lurus ke teras. (02/09-GITSHM)

Pada data (5) di atas Pronomina persona dia mengacu pada orang yang sedang dibicarakan bersifat tunggal. Berdasarkan letak acuan dari pronomina dia yang mengacu kepada Ana dalam tuturan dapat diketahui pronomina dia bersifat endofora. Selain itu, letak tokoh acuan yang berada sesudah pronomina persona dia maka pronomina persona dia termasuk sebagai deiksis endofora yang bersifat katafora. 


\section{E. KESIMPULAN}

Pengacuan deiksis persona yang terdapat dalam kumpulan cerpen pada koran Suara Merdeka Online Edisi November 2018 terdiri atas deiksis eksofora dan endofora. Deiksis eksofora terdapat pada deiksis persona pertama, yaitu sebanyak 36. Pada deiksis endofora memiliki arah pengacuan anafora dan katafora. Deiksis endofora pengacuan anafora yang ditemukan sebanyak 31, sedangkan pada deiksis endofora pengacuan katafora yang ditemukan sebanyak 1.

\section{F.SARAN}

Penelitian tentang deiksis tidak hanya terbatas pada deiksis persona saja. Terdapat jenisjenis lain, antara lain deiksis waktu, tempat, wacana, dan sosial. Penelitian tentang deiksis dengan jenis berbeda dari penelitian ini dengan sumber cerita pendek ataupun karya sastra pada umumnya dapat dilakukan.

\section{DAFTAR PUSTAKA}

Alwi, Hasan. dkk. 2010. Tata Bahasa Baku Bahasa Indonesia. Jakarta: Balai Pustaka.

Abid, Syaiful. 2014. Deiksis Persona Bahasa Musi Desa Pulau Panggung Kecamatan Muara Kelingi Kabupaten Musi Rawas. Jurnal Perspektif Pendidikan, No.2, Vol.8, 43-50.

Ansiska, Mery. 2014. Penggunaan Deiksis Persona dan Tempat dalam Novel Supernova 1 Karya Dee. Jurnal Pendidikan dan Pembelajaran Khatulistiwa, No.3, Vol.3, 1-15.

Farikhah, Ismul. 2018. "Matinya Guru". https://lakonhidup.com/2018/11/25/matinya-guru/. diunduh tanggal 26 November 2018.

Putrayasa, Ida Bagus. 2014. Pragmatik. Yogyakarta: Graha Ilmu.

Rahayu, Umi. 2018. "Gadis Itu Tak Suka Hari Minggu”.https://lakonhidup.com/2018/11/11/gadis-itu-tak-suka-hari-minggu/. diunduhtanggal13 November 2018.

Rovi, A $\quad$ Warits. "Sepasang Kekasih di Atas Loteng”.https://lakonhidup.com/2018/11/18/sepasang-kekasih-di-atas-loteng/. diunduhtanggal22 November 2018.

Sanjaya, Angga T. 2018. "Negeri Asap". https://lakonhidup.com/2018/11/04/negeriasap/.diunduh tanggal 05 November 2018. 
Taufik. 2017. Deiksis Persona Bahasa Indonesia Dialek Ambon. Totobuang, No.2, Vol.5, 325339.

Verhaar, J.W.M. 2012. Asas-asas Linguistik Umum. Yogyakarta: Gadjah Mada University Press.

Yule, George. 1996. Pragmatik. Terjemahan oleh Indah Fajar Wahyuni dan Rombe Mustajab. 2014. Yogyakarta: Pustaka Pelajar. 